
\title{
TEPLOTNÍ MAPOVÁNÍ MĚST: TEPLOTA VS. STRUKTURA, BRNO VS. ČESKÉ BUDĚJOVICE Jan NOVOTNÝ ${ }^{1}$, František ZEMEK ${ }^{1}$, Miroslav PIKL ${ }^{1}$ \\ 1 Ústav výzkumu globální změny, AV ČR, v.v.i., Bělidla 4a, 60200, Brno, ČR novotny.j@czechglobe.cz doi: https://doi.org/10.31490/9788024843988-5
}

\begin{abstract}
Abstrakt
Extrémní letní teploty a $s$ nimi spojené přehřivání veřejného prostoru patří $k$ důsledkům globální změny klimatu, které se projevují v posledních letech v ekosystému měst a ovlivňují kvalitu života jejich občanů.

Smyslem příspěvku je představit pokrok v řešení dvou projektů TAČR, které autorský kolektiv řeší v letech 2019 až 2021.

První z nich, s názvem „Tvorba nástrojů pro plánování a hodnocení ekologického benefitu městské vegetace", má za cíl vytvoření komplexní metodiky a software pro objektivní hodnocení ekosystémových funkcí městské zeleně za účelem ohodnocení jejích ekosystémových služeb. Druhý projekt, s názvem „Teplotní komfort v obcích: pocitový vjem obyvatel, fyzikální skutečnost, role zeleně“, má za cíl porovnat vjemy obyvatel týkající se teplotního komfortu $v$ obcích $s$ fyzikální skutečností teplotních charakteristik zachycených prostřednictvím moderních metod pozemního a leteckého DPZ. Více informací o cílech projektů obsahuje referát ve sborníku sympozia GIS Ostrava 2019.

Letošní příspěvek bude zaměřen především na ukázky z leteckých dat pořízených v létě 2019 pro krajská města Brno a České Budějovice. Na úrovni různých prostorových celků $v$ rámci města analyzujeme vztah mezi strukturou města a teplotním režimem. $\mathrm{K}$ tomu využíváme data laserového skenování a hyperspektrální data od viditelné, přes infračervenou až do termální oblasti elektromagnetického spektra.
\end{abstract}

\section{Abstract}

Extreme summer temperatures connected with overheating of public space in urban ecosystems have been identified as a consequence of climate change and as a factor negatively influencing the quality of living conditions for people.

The main aim of this contribution is to present the progress in the two research projects that started in 2019. The first project, titled "Development of instruments for planning and assessment of ecological benefit of greenery in towns", aims to develop a complex methodology and software for an objective assessment of urban greenery ecosystem functions in order to evaluate the ecosystem services. The second project, titled "Thermal comfort in urban areas: human perception, physics based reality, role of greenery", is focused on a multidisciplinary assessment of thermal comfort in human settlements.

Products of an airborne campaign conducted in summer 2019 in two regional capitals (Brno, České Budějovice) will be presented. Based on airborne laser scanning data and hyperspectral data from visible to thermal wavelengths we assess the dependencies between city structure and thermal regime.

Klíčová slova: ekosystémové služby; sídelní zeleň; mapování teplot; hyperspektrální data; letecké laserové skenování.

Keywords: ecosystem services; urban greenery; thermal mapping; hyperspectral data; airborne laser scanning. 


\section{ŘEŠENÍ PROJEKTU゚ V ROCE 2019}

V rámci projektu „Tvorba nástrojů pro plánování a hodnocení ekologického benefitu městské vegetace“ byla na základě literární rešerše zpracována kostra modulů, které tvoří metodický postup hodnocení jednotlivých ekosystémových funkcí: 1) chladící efekt vegetace, 2) ukládání uhlíku $\left.\left(\mathrm{CO}_{2}\right), 3\right)$ záchyt pevných částic znečištujících ovzduší, 4) estetická a kulturně rekreační funkce zeleně, 5) vliv zeleně na snižování hluku.

Z městských inventarizací a pasportů zeleně byla navržena databáze druhů dřevin typických pro použití ve městech střední Evropy. Následně byla databáze doplněna o jednotlivé vlastnosti a dendrometrické parametry nutné jako vstupy do programových modulů (např. čeled', taxon, vzhled habitu, krytosemennost, nahosemennost, typ olistění, hloubka a typ kořenového systému, průměrný věk, výška, odolnost vůči zasolení, alergenní vlastnosti). Databáze bude dále doplňována dle potřeb jednotlivých EF/ES (např. odhady listové plochy (LAI) použitých dřevin z Globální databáze LAI stromů a keřů) a propojena s meteorologickými údaji z meteo web serverů.

V rámci projektu „Teplotní komfort v obcích: pocitový vjem obyvatel, fyzikální skutečnost, role zeleně“ byla nasnímána letecká data pro 5 plánovaných lokalit: Brno, České Budějovice, Lišov, Sloup\&Šošũvka v Moravském Krasu a Vlčnov v okrese Uherské Hradiště. Lokality byly vybrány na základě kontrastnějších charakteristik topografie území a s tím souvisejícím mikroklimatem obcí (vlhčí a sušší), počtu obyvatel (větší města/vesnice) a $v$ neposlední řadě předem zjištěného zájmu představitelů obcí o řešení problematiky teplotního komfortu $v$ urbánních systémech.

Souběžně s leteckou kampaní probíhal též sběr pozemních dat - o spektrálních vlastnostech povrchů a dalších veličinách potřebných pro kalibraci leteckých dat; a dále měření mikroklimatu pro analýzu vztahu mezi teplotou povrchů a pocitovou teplotou.

Další aktivitou bylo dotazníkové šetření $\mathrm{k}$ hodnocení vnímaného vystavení horku v Českých Budějovicích a v Brně. V roce 2019 jsme získali data pro první studii, jejímž cílem bylo navrhnout a empiricky testovat psychometrické vlastnosti škály pro měření postojů $k$ vnímání teploty na daném místě, jehož fyzikální charakteristiky (např. zastoupení tříd pokryvu, orografie, teplota, atd.) jsme schopni zjistit z leteckých dat DPZ a pozemních měření.

\section{LETECKÁ DATA: TEPLOTA A STRUKTURA - UKÁZKY}

Ke studiu vztahů mezi strukturou města a teplotním režimem využíváme letecká data laserového skenování a hyperspektrální data od viditelné, přes infračervenou až do termální oblasti elektromagnetického spektra, pořizená technickou infrastrukturou FLIS provozovanou CzechGlobe (http://olc.czechglobe.cz/flis/).

Na lokalitě Brno bylo naplánováno celkem 26 linií s orientací 330/150 , které pokrývají většinu katastrálního území. Snímání probíhalo 31. 8. 2019 z letové výšky cca $1900 \mathrm{~m}$ s překryvem $40 \%$, což odpovídá prostorovému rozlišení 0,8 / $2 \mathrm{~m}$ (CASI / SASI, TASI). Současně se snímáním leteckých dat bylo na šesti plochách provedeno měření spektrální odrazivosti vybraných referenčních povrchů (ASD FieldSpec4) a měření propustnosti atmosféry (Microtops).

Letecké snímání v oblasti České Budějovice \& Lišov proběhlo 24. 7. 2019 za bezoblačných podmínek. Snímání předcházela perioda vyšších teplot, s nízkou oblačností a vysokými úhrny slunečního záření. Na lokalitě České Budějovice bylo naplánováno celkem 15 linií s orientací 340/160', které pokrývají intravilán a převážnou část katastrálního území. Orientace linií byla provedena s ohledem na čas snímání a časovou náročnost nasnímání dané lokality tak, aby byla minimalizována plocha stínů a efekt anizotropie odrazivosti měřených povrchů. Snímání z letové výšky cca 1000 m s překryvem 30 \% odpovídá prostorovému rozlišení 0,5 / $1 \mathrm{~m}$ (CASI / SASI, TASI).

Data z hyperspektrálního termálního skeneru TASI jsou předzpracována procesem radiometrické, atmosférické a geometrické korekce. Emisivita a jasová teplota povrchu (Obr. 1. a Obr. 2.) je odhadnuta pomocí algoritmu TES (Temperature and Emissivity Separation). 
Data z teplotní mapy byla analyzována ve vztahu k struktuře pokryvu na úrovni jednotlivých městských částí a na úrovni základních sídelních jednotek, které vymezují dílčí části obcí $s$ víceméně jednotnou architektonickou strukturou a typem využití území. Průměrná teplota povrchů v jednotlivých základních sídelních jednotkách je prezentována na Obr. 3 a Obr. 4 a Ize sledovat rozdíly mezi zástavbou různého typu, většími plochami zeleně, oblastmi výrobních hal a naopak oblastmi lesa a vodních ploch $v$ okolí města.

S cílem provést základní klasifikaci pokryvu byly extrahovány z leteckých dat následující vstupní vrstvy:

A z bodového mračna

- $\quad$ rastr výšky objektů (nDSM)

- $\quad$ rastr amplitudy (intenzity odrazu ve vlnové délce laseru)

- $\quad$ rastr šířky odraženého echa (pulse width)

- $\quad$ rastr počtu odrazů z jednoho paprsku (nr. of echos)

A z hyperspektrálního snímku

- $\quad$ poměrový index NDVI (z bandů 33 a 13 senzoru CASI, vlnové délky 838 a 553 nm)

- $\quad$ poměrový index typu NDVI pro obsah vody (z bandů 23 a 38 senzoru SASI, vlnové délky 1287 a $1512 \mathrm{~nm})$

Klasifikace do čtyř základních tříd - budovy, silnice (zpevněné povrchy), stromy (vysoká vegetace), trávníky (nízká vegetace) - byla provedena v softwaru eCognition. Objekty byly segmentovány jako homogenní celky metodou multiresolution segmentation se vstupem šesti výše zmíněných vrstev. Rozdělení do tříd bylo založeno na prahování veličin výška a NDVI. Ukázka výsledku klasifikace je na Obr. 5.

Kompletní mozaika čtyř tříd byla protnuta s vektorem základních sídelních jednotek a zonální statistiky vyjadřující poměr jednotlivých tříd v polygonu byly srovnány s hodnotami mediánu povrchové teploty. Prínos jednotlivých typů povrchu pro snížení nebo nárůst teploty ukazuje Obr. 6 a Obr. 7.

Obě datové sady potvrzují, že nejvyšší přínos pro snížení teploty má vzrostlá vegetace, a to až na úrovni $2^{\circ} \mathrm{C}$ na 10 procent zastoupení. Nižší rozsah $v$ teplotách a tedy i změnách teploty $v$ Brně oproti Č. Budějovicím je dán rozdílným termínem a meteorologickými podmínkami při snímání (a před ním).

\section{PODĚKOVÁNÍ A ZDROJE}

\section{Projektové návrhy a průběžné zprávy:}

Tvorba nástrojů pro plánování a hodnocení ekologického benefitu městské vegetace (TAČR Epsilon TH04030496-N)

Teplotní komfort v obcích: pocitový vjem obyvatel, fyzikální skutečnost, role zeleně (TAČR Eta TL02000322N)

\section{Webové stránky:}

Infrastruktura FLIS: http://olc.czechglobe.cz/flis/

Příspěvek ve sborníku GIS Ostrava 2019:

http://gisak.vsb.cz/GIS_Ostrava/GIS_Ova_2019/sbornik/papers/gis20195c01288b5bf33.pdf 


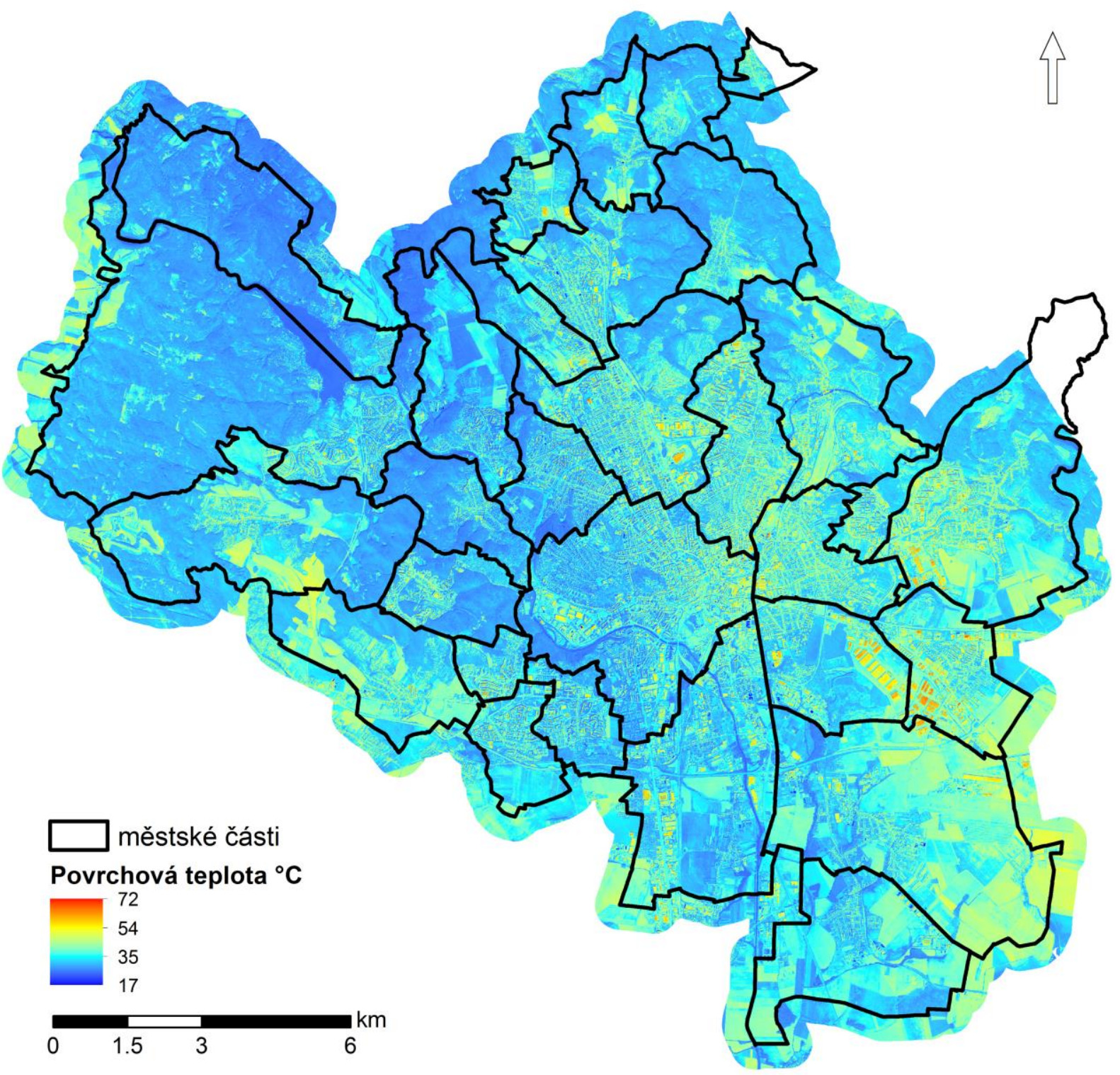

Obr. 1. Mapa teploty povrchů v katastru města Brna nasnímaná 31. 8. 2019. 


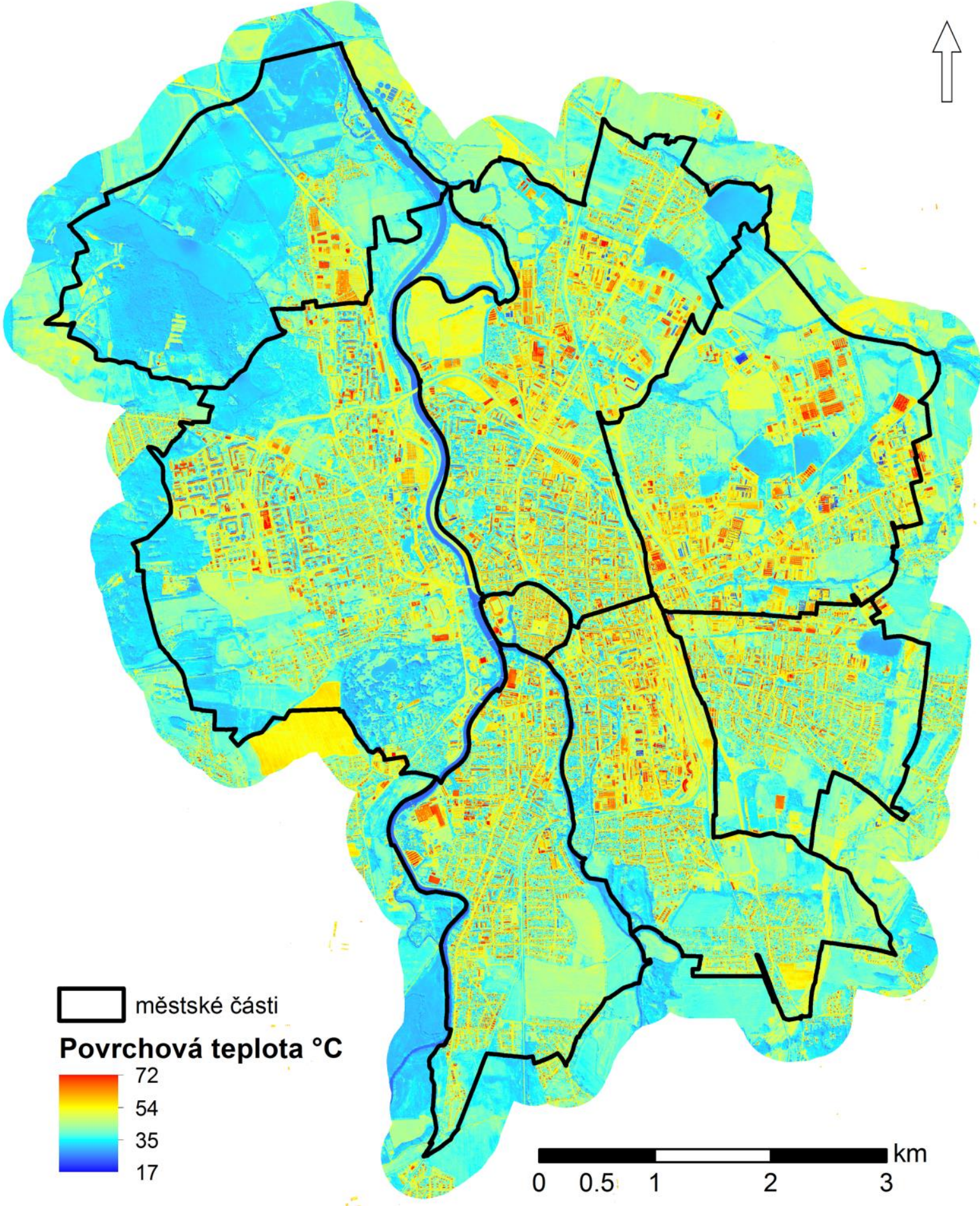

Obr. 2. Mapa teploty povrchů v katastru města České Budějovice nasnímaná 24. 7. 2019. 


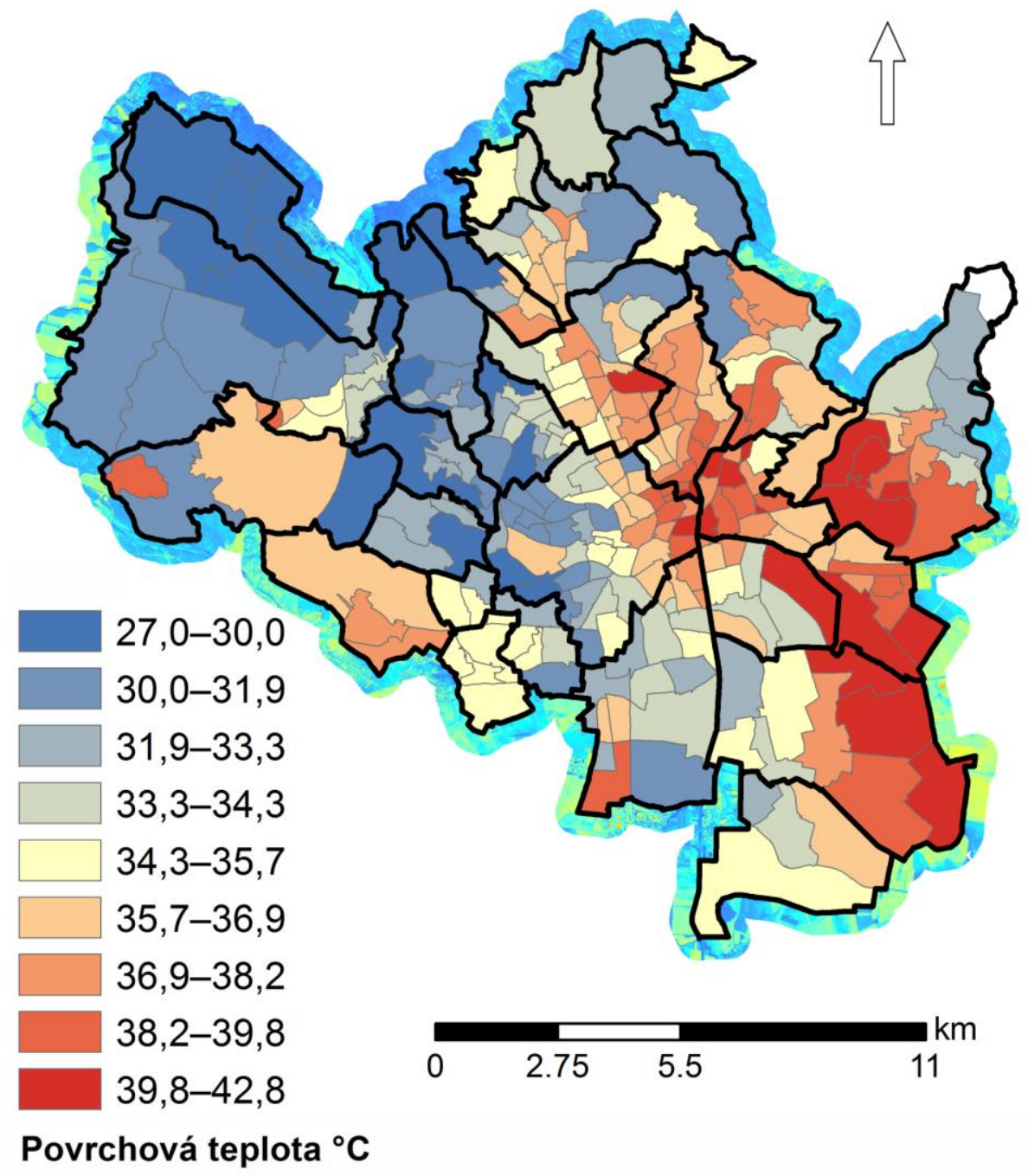

Obr. 3. Průměrná teplota povrchů v základních sídelních jednotkách v katastru města Brna.

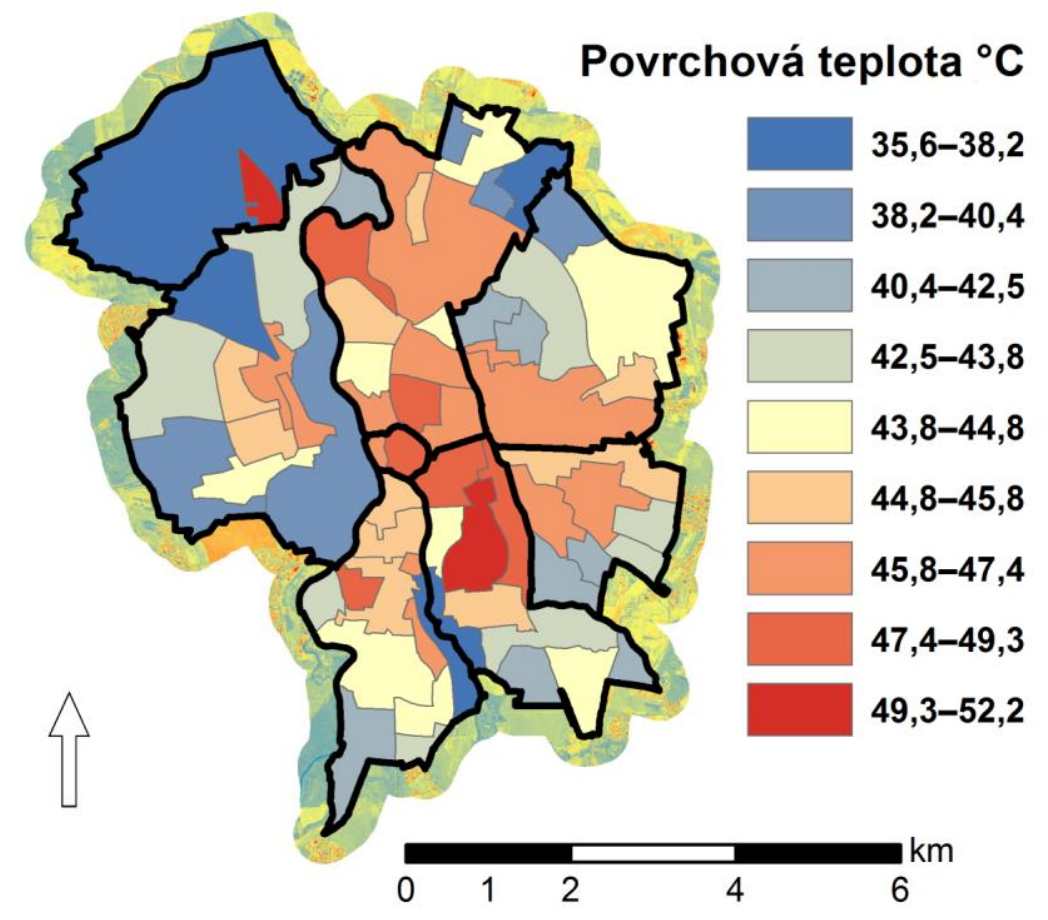

Obr. 4. Průměrná teplota povrchů v základních sídelních jednotkách v katastru města České Budějovice. 


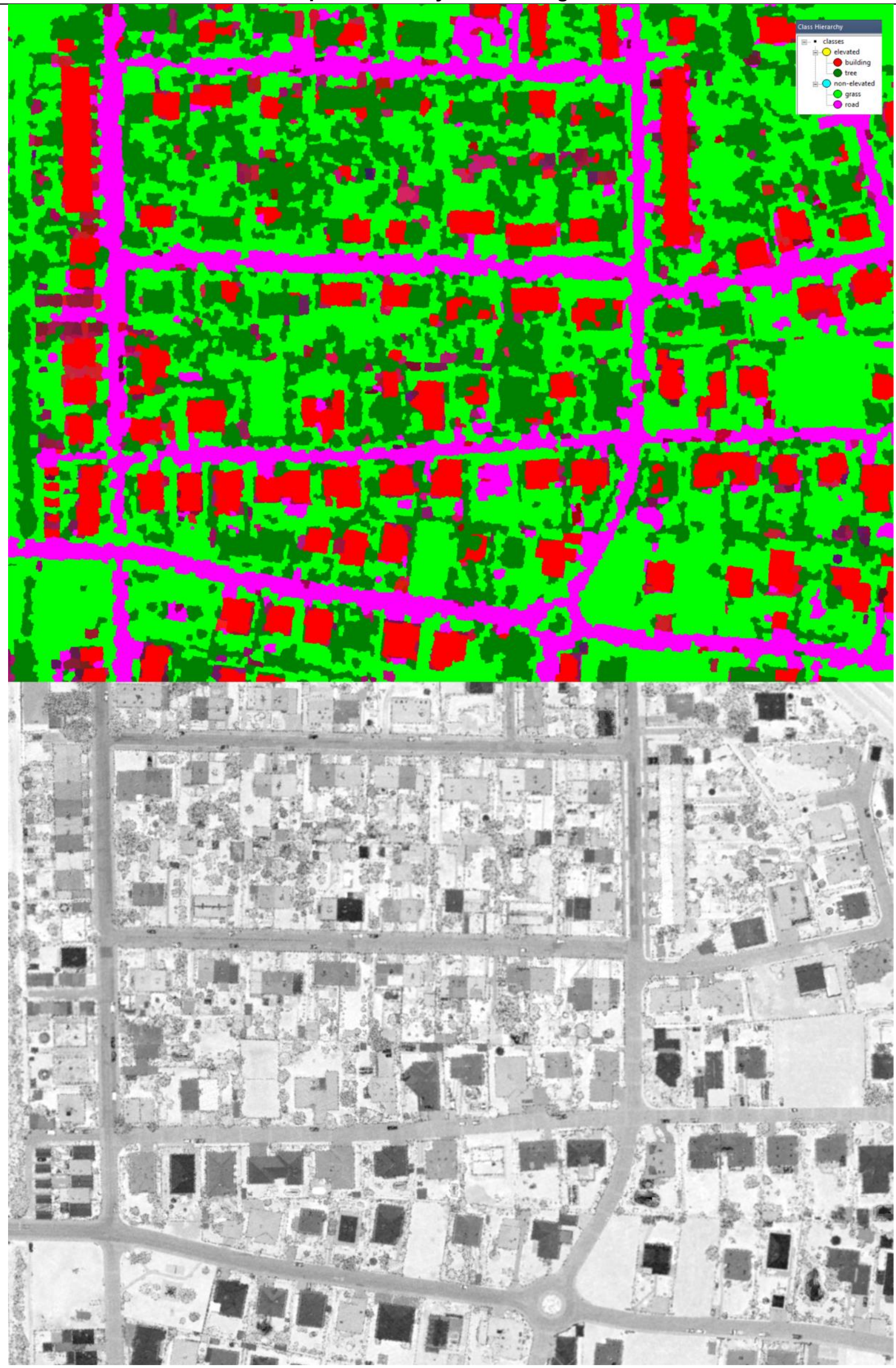

Obr. 5. Ukázka výsledků klasifikace pokryvu do čtyř základních tříd (nahoře). Na spodním obrázku je jedna ze vstupních vrstev - rastr amplitudy = odrazivosti povrchů na vinové délce laseru. 

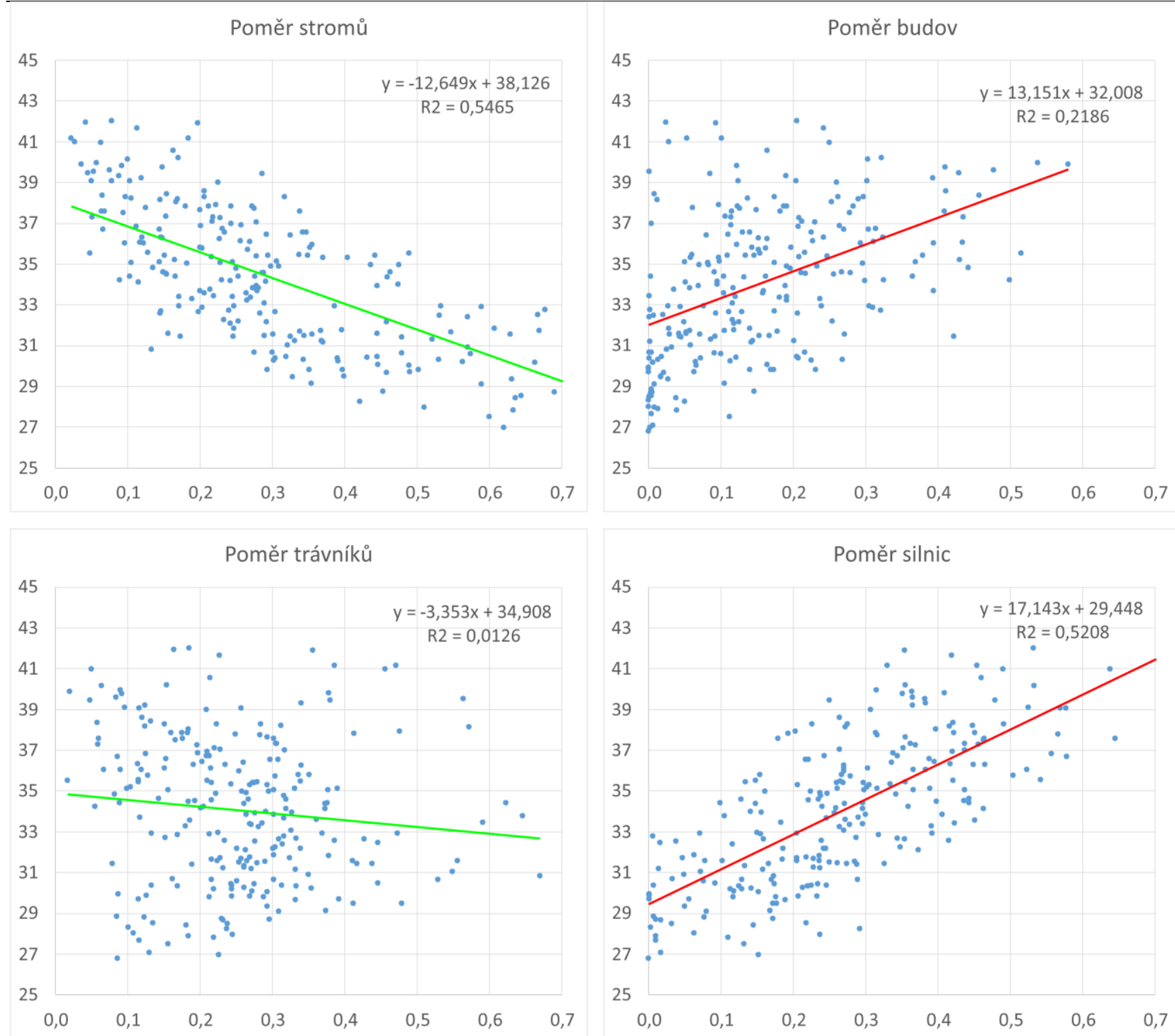

Obr. 6. Znázornění prínosu jednotlivých typů povrchu pro snížení nebo nárůst teploty na úrovni základních sídelních jednotek v Brně. Osa $\mathrm{X}$ - poměrné zastoupení třídy [-], osa $\mathrm{Y}$ - teplota povrchu $\left[{ }^{\circ} \mathrm{C}\right]$. 


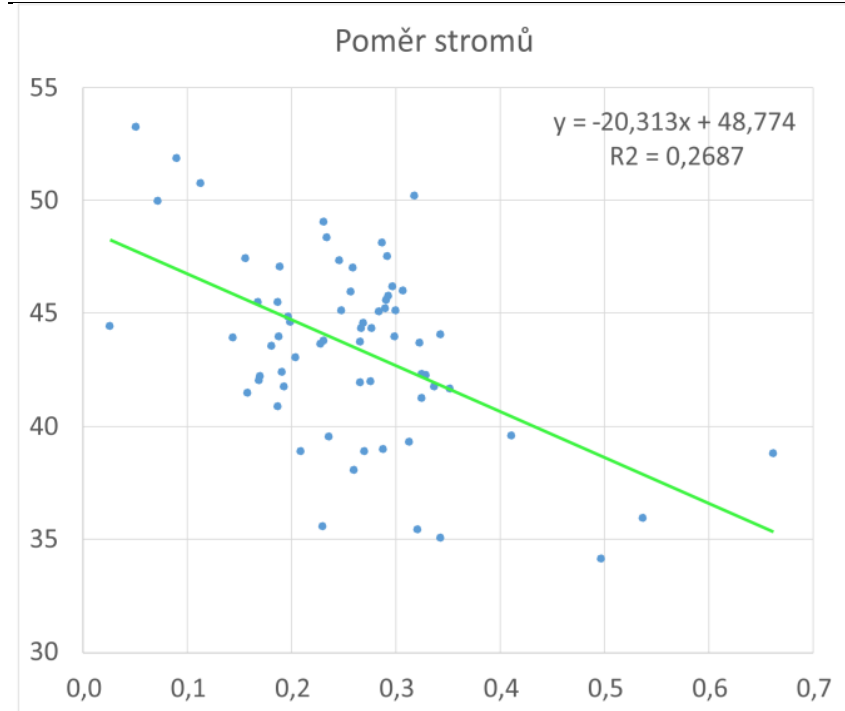

Poměr budov

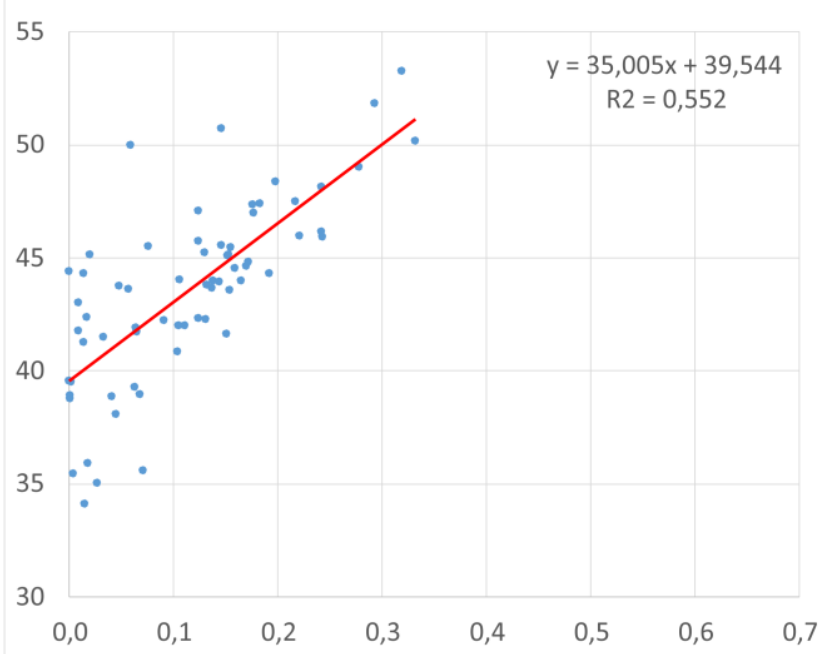

Poměr trávníků

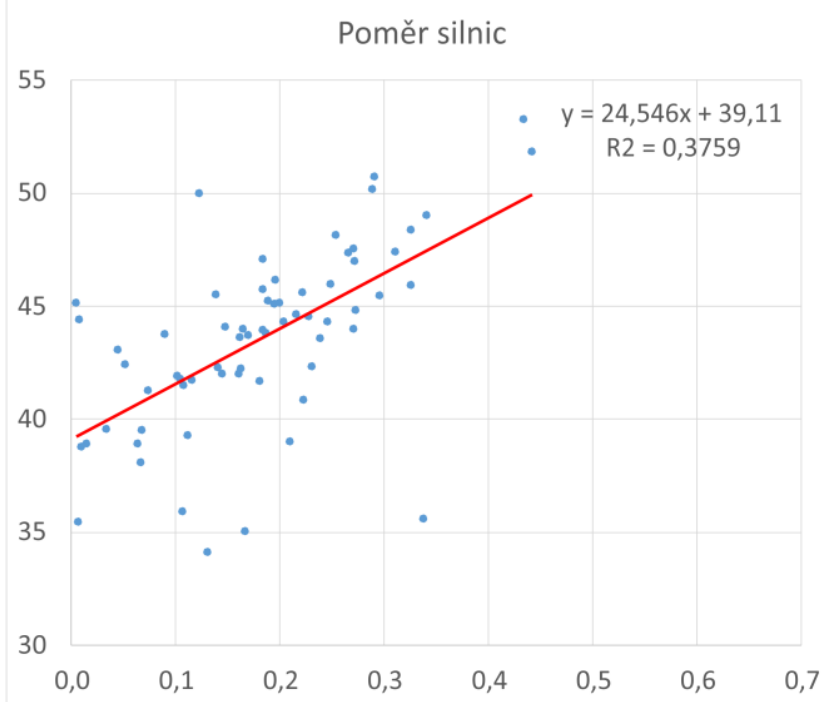

Obr. 7. Znázornění prínosu jednotlivých typů povrchu pro snížení nebo nárůst teploty na úrovni základních sídelních jednotek v Českých Budějovicích. Osa $X$ - poměrné zastoupení třídy [-], osa $Y$ - teplota povrchu $\left[{ }^{\circ} \mathrm{C}\right]$. 